\title{
Structural Studies on $\mathrm{Ag}_{2} \mathrm{O}-\mathrm{P}_{2} \mathrm{O}_{5}$ Glasses
}

\author{
Gomaa El-Damrawi, Abdelmajued Hassan, Hamdy Doweidar, Ahamed Shaboub
}

Glass Research Group, Physics Department, Faculty of Science, Mansoura University, Mansoura, Egypt

Email: gomaaeldamrawi@gmail.com

How to cite this paper: El-Damrawi, G., Hassan, A., Doweidar, H. and Shaboub, A. (2017) Structural Studies on $\mathrm{Ag}_{2} \mathrm{O}-\mathrm{P}_{2} \mathrm{O}_{5}$ Glasses. New Journal of Glass and Ceramics, 7, 77-89.

https://doi.org/10.4236/njgc.2017.73007

Received: May 25, 2017

Accepted: July 4, 2017

Published: July 7, 2017

Copyright ( $\odot 2017$ by authors and Scientific Research Publishing Inc. This work is licensed under the Creative Commons Attribution International License (CC BY 4.0).

http://creativecommons.org/licenses/by/4.0/ (c) (i) Open Access

\begin{abstract}
Silver phosphate glasses of general formula $x \mathrm{Ag}_{2} \mathrm{O} \cdot(100-\mathrm{x}) \mathrm{P}_{2} \mathrm{O}_{5}$ have been investigated over compositional range from $x=40$ to $62.5 \mathrm{~mol} \%$. The local structure around phosphorus atom has been studied via ${ }^{31} \mathrm{P}$ nuclear magnetic resonance. The distribution of $\left[\mathrm{PO}_{4}\right] \mathrm{Q}^{n}$ species as a function of composition has been shown to slightly deviate from the simple binary alkali phosphate model. An anomalous behavior has been recorded and interpreted in terms of mixed ring-chain effect in metaphosphate composition. The splitting of NMR spectra into sub resonances is assigned to different binding sites characterizing $\mathrm{Q}^{1}$ ring and $\mathrm{Q}^{1}$ chain structure. Higher $\mathrm{Ag}_{2} \mathrm{O}$ concentration ( $\geq 50 \mathrm{~mol} \%$ ) leads to formation of phosphate groups with specific resonance peaks which are mainly related to pyro and orthophosphate species. The rate of change of the chemical shift of the ${ }^{31} \mathrm{P}$ NMR depends on the bond type, which in turn reflects the extent of double bonding between phosphorus and oxygen atoms. Increasing concentration of $\mathrm{Q}^{0}$ with increasing $\mathrm{Ag}_{2} \mathrm{O}$ content leads to decreasing quantities of bridging and double bonds. As a consequence, specific symmetric resonance peak of higher intensity and chemical shift $\left(\mathrm{Q}^{0}\right)$ is a feature of silver rich glasses (orthophosphate). The latter species is therefore proposed to compose of separated membered rings, which cause deshielding of phosphate units. XRD and EDP studies have shown that, amorphous phosphate network is the dominant structure of glasses containing $\leq 55 \mathrm{~mol} \%$ $\mathrm{Ag}_{2} \mathrm{O}$. Some ordered and well crystallized phases are formed at higher $\mathrm{Ag}_{2} \mathrm{O}$ concentration. Increasing non-bridging oxygen atoms is shown to have the main effect on crystallization behavior. Orthophosphate composition is the most crystalline one among the other compositions (ultra, meta- and pyrophosphate). Presence of orthophosphate species which typically contains highest concentration from isolated $\mathrm{Q}^{0}$ units is the main reason for building up crystalline $\mathrm{Ag}_{3} \mathrm{PO}_{4}$ phosphate phase.
\end{abstract}

\section{Keywords}

Nuclear Magnetic Resonance, Chemical Shift, Phosphate Species, Orthophosphates 


\section{Introduction}

It was known that $\mathrm{P}_{2} \mathrm{O}_{5}$ consists of a three dimensional (3-D) network of trigonally connected tetrahedral $\mathrm{PO}_{4}$ units with a $\mathrm{P}=\mathrm{O}$ unit [1] [2] [3] [4]. Depending on the number of bridging oxygen atoms in $\mathrm{Q}^{\mathrm{n}}$ species $(\mathrm{n}=3,2,1,0)$, the phosphate tetrahedral units can be described by containing high concentration of $\mathrm{Q}^{3}$ species in glasses of lower modifier content [2] [3] [4] [5]. Addition of modifier oxide degrades the 3-D network through generation of nonbridging oxygens (NBO). Continuous increasing of fraction of NBO with increasing modifier oxide was interpreted in terms of an increasing long-chain $\mathrm{PO}_{2}$ groups in the glass [2] [3] [6] [7] [8] [9] [10]. This mechanism causes a structural transition from a 3-D network of interconnected $\mathrm{PO}_{4}$ groups to a 1-D chain structure of intermediate-range order. This denotes a degradation and transformation of a fully polymerized neutral unit $\left(\mathrm{Q}^{3}\right)$ of extremely high shielded structure to new phosphate units $\left(\mathrm{Q}^{2}-\mathrm{Q}^{0}\right)$ of higher NBO concentration. Specifically, $\mathrm{Q}^{2}$ is based on chains and rings and it has one negative charge. $\mathrm{Q}^{1}$ means two tetrahedral units connected by a corner. Finally, $\mathrm{Q}^{0}$ is referred to isolated and less shielded phosphate tetrahedral units with three negative charges.

The structure of phosphate glasses strongly depends on specific structural factor namely $\mathrm{R}$ which represents modifier $(\mathrm{M})$ to phosphor $(\mathrm{P})$ ratio in the glass composition [10] [11] [12]. The metaphosphate $\left(\mathrm{Q}^{3}\right)$ glasses have relatively low $\mathrm{R}$ values $(<1)$. The pyrophosphate glasses have intermediate $\mathrm{R}(\sim 1)$. This composition is consisting of $\mathrm{Q}^{1}$ as the major structural units. The orthophosphate glasses typically have the highest $\mathrm{R}(>1)$ and contain isolated $\mathrm{Q}^{0}$ units.

Incorporation of metal oxide or alkali oxide in phosphate glasses [10] [13] [14] [15] is commonly consumed in breaking down of the P-O-P linkages and formation of P-OM (M: metal) bonds. The prevalence of particular $\mathrm{Q}^{\mathrm{n}}$ unit depends on the nature and concentration of the cations present in the glass [15] [16].

Many of previous studies were carried out on phosphate glasses modified by alkali or alkaline earth oxides in the region of ultra, meta and pyrophosphate [2] [3] [17] [18] [19]. On the other hand, limited reports on modification by $\mathrm{Ag}_{2} \mathrm{O}$, particularly in pyro- and orthophosphate regions, have been considered before. Therefore, this work is devoted to shed light on structural role of $\mathrm{Ag}_{2} \mathrm{O}$ in enriched modified glasses. In addition, we make use of the advantage of the high resolution modern NMR spectroscopy to report on anomalous behavior of metaphosphate glass, which to our knowledge, has not been reported before.

\section{Experimental Work}

Binary silver phosphate glasses in the system, $x \mathrm{Ag}_{2} \mathrm{O} \cdot(100-\mathrm{x}) \mathrm{P}_{2} \mathrm{O}_{5}$ where $40 \leq \mathrm{x}$ $\leq 62.5 \mathrm{~mol} \%$ have been prepared by mixing $\mathrm{AgNO}_{3}$, and $\mathrm{NH}_{4} \mathrm{H}_{2} \mathrm{PO}_{4}$ as starting raw materials. $\mathrm{NH}_{4} \mathrm{H}_{2} \mathrm{PO}_{4}$ was heated in a porcelain crucible at $300^{\circ} \mathrm{C}$ for $30 \mathrm{~min}$ in order to evaporate ammonia and water. Then $\mathrm{AgNO}_{3}$ was added and the mixture was melted at temperature between $900^{\circ} \mathrm{C}$ and $1100^{\circ} \mathrm{C}$, depending on the composition. The melt was swirled severally to attain homogeneity. The glass 
samples were obtained by pouring the melt onto flat plate. The glasses were kept in a desiccator until required.

$\mathrm{X}$-ray diffraction (XRD) was used to examine the amorphous nature of the samples. The patterns were obtained by using a Burker D8 Advance powder XRD instrument. It is fitted with a Vantech super speed position sensitive detector and a $\mathrm{Cu} \mathrm{K \alpha} \mathrm{X}$-ray tube with a Gobel mirror. Measurements were made over the range $4^{\circ}$ to $70^{\circ}$ in $2 \theta$ scale.

The internal micro structural features of glass samples were investigated using a transmission electron microscope TEM model JEOL-JEM-2100, Japan equipped (EDP) with an electron diffraction pattern unit. TEM investigations were performed at an electron acceleration voltage of $200 \mathrm{Kv}$.

Infrared spectra of the glasses were measured by a Mattson 5000 FTIR spectrometer in the range 400 and $2000 \mathrm{~cm}^{-1}$. The measurements were carried out on powdered samples which is mixed with $\mathrm{KBr}$ ( $1 \mathrm{wt} \%)$, and then compressing the mixtures to form pellets for measurements.

The distribution of $\mathrm{Q}^{\mathrm{n}}$ of phosphate unit obtained from ${ }^{31} \mathrm{P}$ NMR spectra of selected glasses $(x=40,50$, and $62.5 \mathrm{~mol} \%)$. The investigations were carried out using JEOL RESONANCE GSX-500 High Resolution Solid state MAS NMR spectrometer. The spectra were obtained at high external magnetic field (11.747T), at a frequency of $160.47 \mathrm{MHz}$ and spinning rate of $40 \mathrm{MHz}$.

\section{Results and Discussions}

$\mathrm{X}$-ray diffraction patterns of glasses in $\mathrm{xAg}_{2} \mathrm{O} \cdot(100-\mathrm{x}) \mathrm{P}_{2} \mathrm{O}_{5}$ system are shown in Figure 1 and Figure 2. Broad pattern characterizes vitreous nature of the invest-

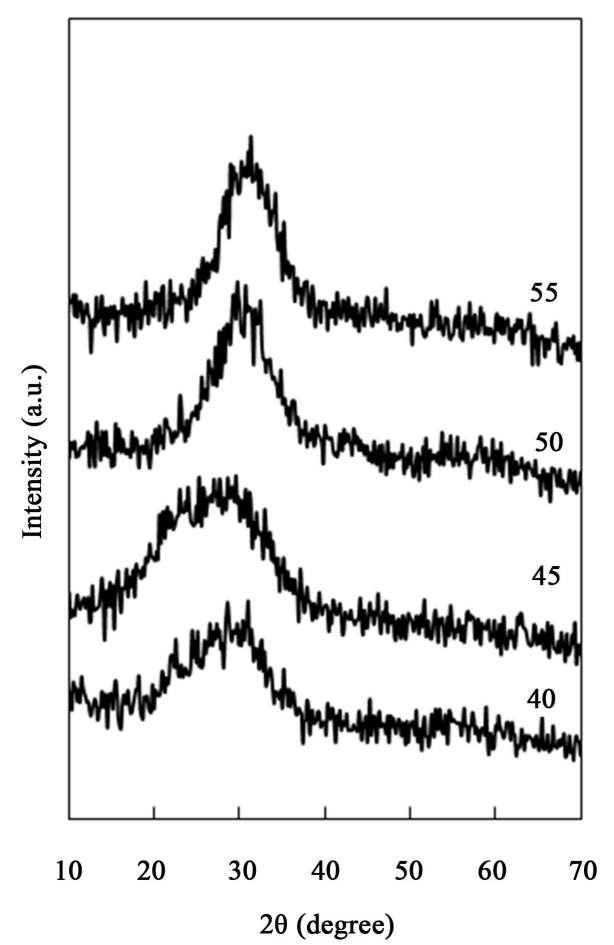

Figure 1. XRD patterns of glasses containing 40, 45, 50 and $55 \mathrm{~mol} \% \mathrm{Ag}_{2} \mathrm{O}$. 


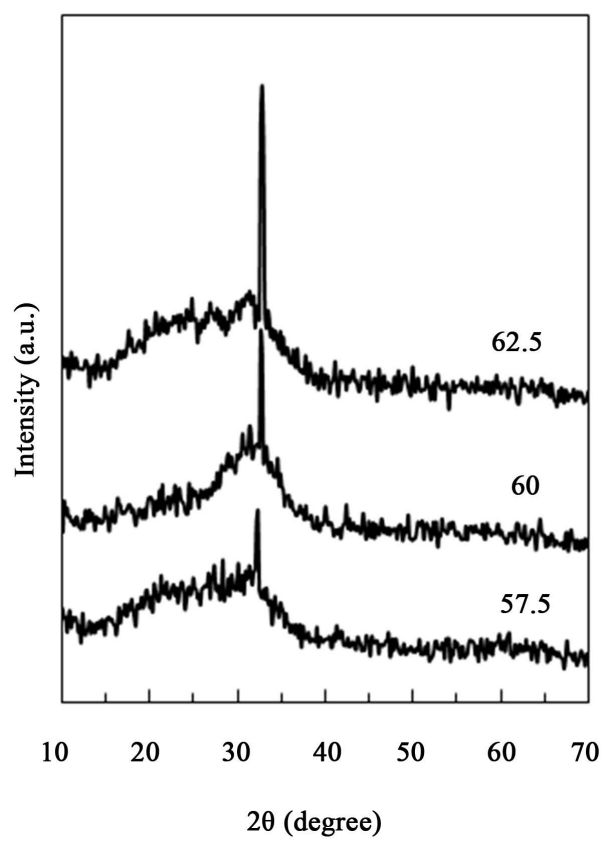

Figure 2. XRD patterns of glasses containing 57.5, 60 and $62.5 \mathrm{~mol} \% \mathrm{Ag}_{2} \mathrm{O}$.

tigated glass is obviously observed between $2 \theta=18^{\circ}-38^{\circ}$. This amorphous nature is dominated in glasses of 40, 45, 50 and $55 \mathrm{~mol} \% \mathrm{Ag}_{2} \mathrm{O}$, Figure 1. On the other hand, significant changes were observed in $\mathrm{Ag}_{2} \mathrm{O}$ rich glasses ( $>55 \mathrm{~mol} \%$ $\mathrm{Ag}_{2} \mathrm{O}$ ). XRD patterns which are shown in Figure 2 contain sharp diffraction peaks superimposed on the wide hump of the glassy network. Specifically, X-ray diffraction patterns of the sample containing 57.5, 60 and $62.5 \mathrm{~mol} \% \mathrm{Ag}_{2} \mathrm{O}$ are characterized by presence of the intense sharp peak centered at $2 \theta=31.9^{\circ}$. Presence of these diffraction lines may indicate formation of more ordered species that characterize metaphosphate $\left(\mathrm{Ag}_{2} \mathrm{PO}_{3}\right)$, pyrophosphate $\mathrm{Ag}_{4} \mathrm{P}_{2} \mathrm{O}_{7}$ and orthophosphate $\mathrm{Ag}_{3} \mathrm{PO}_{4}$ units distributed in the main phosphate network [14] [15] [16]. $\mathrm{Ag}_{4} \mathrm{P}_{2} \mathrm{O}_{7}$ is the most dominant phase found particularly in pyrophosphate glass network containing $57.5 \mathrm{~mol} \% \mathrm{Ag}_{2} \mathrm{O}$. X-ray diffraction data obtained for the resulting glass were found to be fitted with those reported for $\mathrm{Ag}_{4} \mathrm{P}_{2} \mathrm{O}_{7}$ [JCPDS Cards File No. 11-0637]. Increasing intensity of the sharp peak with increasing $\mathrm{Ag}_{2} \mathrm{O}$ may reflect an important feature for the studied glasses. This feature could be attributed to formation of $\left(\mathrm{Ag}_{4} \mathrm{P}_{2} \mathrm{O}_{7}\right)$ pyrophosphate and $\mathrm{Ag}_{3} \mathrm{PO}_{4}$ orthophosphate crystalline phases [JCPDS Cards File No. 89-7399]. The principal peak at $31.9^{\circ}$ (triplet) for reflections (211), (112) and (300) is the main diffraction pattern.

Additional evidence for the formation of an $\mathrm{Ag}_{4} \mathrm{P}_{2} \mathrm{O}_{7}$ and $\mathrm{Ag}_{3} \mathrm{PO}_{4}$ crystalline phases in silver rich glasses was also found by examination through TEM and EDP (Figure 3). It appears from EDP that there is a certain degree of crystallinity in glass of $62.5 \mathrm{~mol} \% \mathrm{Ag}_{2} \mathrm{O}$. The feature appeared in EDP is in agreement with that obtained from XRD of the same glass, since sharp single diffraction is clearly evidenced from both XRD and EDP patterns, Figure 3(a). The remain glass network seems to be in amorphous state as represented by EDP (b), Figure 3. 


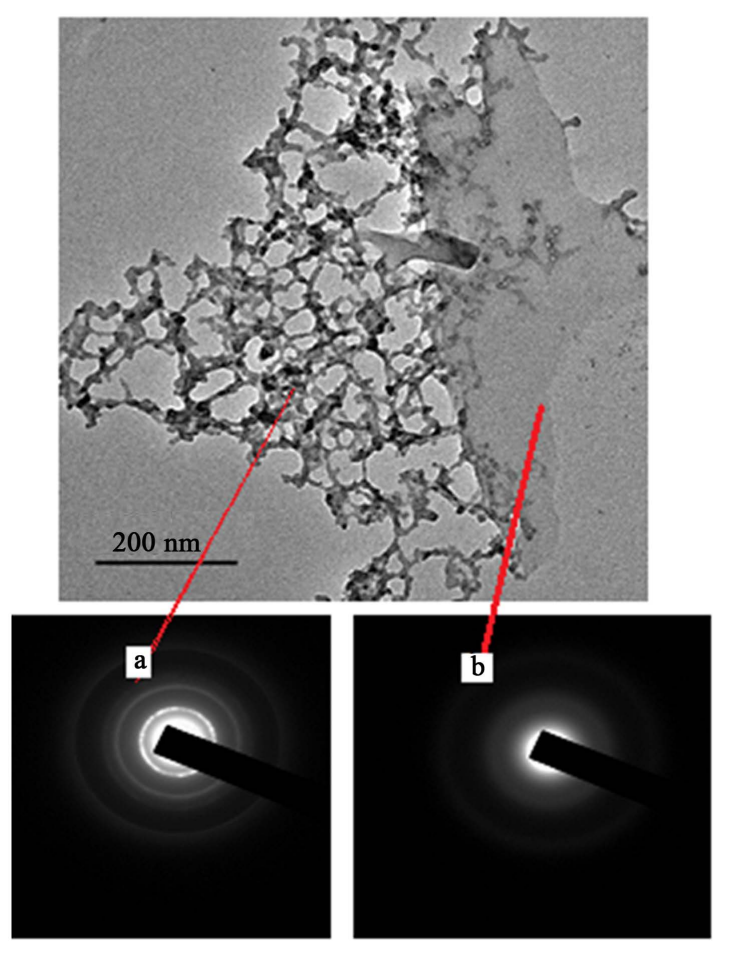

Figure 3. TEM and EDP of $\mathrm{Ag}_{2} \mathrm{O}$ rich glass (62.5 mol\% $\mathrm{Ag}_{2} \mathrm{O}$ ).

Formation of high concentration of non-bridging oxygen (NBO) in silver rich glasses are considered as the main reason for building crystallized phosphate species as resolved by both XRD and TEM. When the glass network is constructed from symmetric type of units such as orthophosphate (in $62.5 \mathrm{Ag}_{2} \mathrm{O}$ glass), symmetric and ordered phase enriched with NBO species are also constructed [11] [16]. This consideration is clearly verified from both XRD and EDP of glass containing $62.5 \mathrm{~mol} \% \mathrm{Ag}_{2} \mathrm{O}$, since one resolved XRD peak (Figure 2) and single diffraction of electron patterns (Figure 3(a)) are clearly evidenced to represent $\mathrm{Q}^{0}$ in orthophosphate $\mathrm{Ag}_{3} \mathrm{PO}_{4}$ crystalline units.

\section{${ }^{31}$ P MAS-NMR Spectroscopy}

NMR spectra of phosphorus nuclei are very complicated due to several interconnected side bands which in some cases dilute the real spectra [15] [20]. Present NMR technique has succeeded in dealing with a problem or difficulty which comes from signal of side bands. In this regard, high spinning frequency $(21 \mathrm{kHz})$ and high external magnetic field $(11.74 \mathrm{~T})$ are both carefully applied during time scan of measurement. Therefore, side bands free NMR spectra of isotropic chemical shift are simply obtained. Then anisotropic distribution of both side bands and chemical shift are not probable in present study. Only real isotropic chemical shift of NMR spectra free from side bands is obtained.

Figure 4 shows ${ }^{31}$ PNMR spectra of glasses containing 40, 50 and $62.5 \mathrm{~mol} \%$ $\mathrm{Ag}_{2} \mathrm{O}$. These spectra represent glasses in selected compositions which are found in metaphosphate (40 $\mathrm{mol} \%)$, pyrophosphate $(50 \mathrm{~mol} \%)$ and orthophosphate (62.5 mol\%) extremes. It can be shown from Figure 4 and Table 1 that there are 

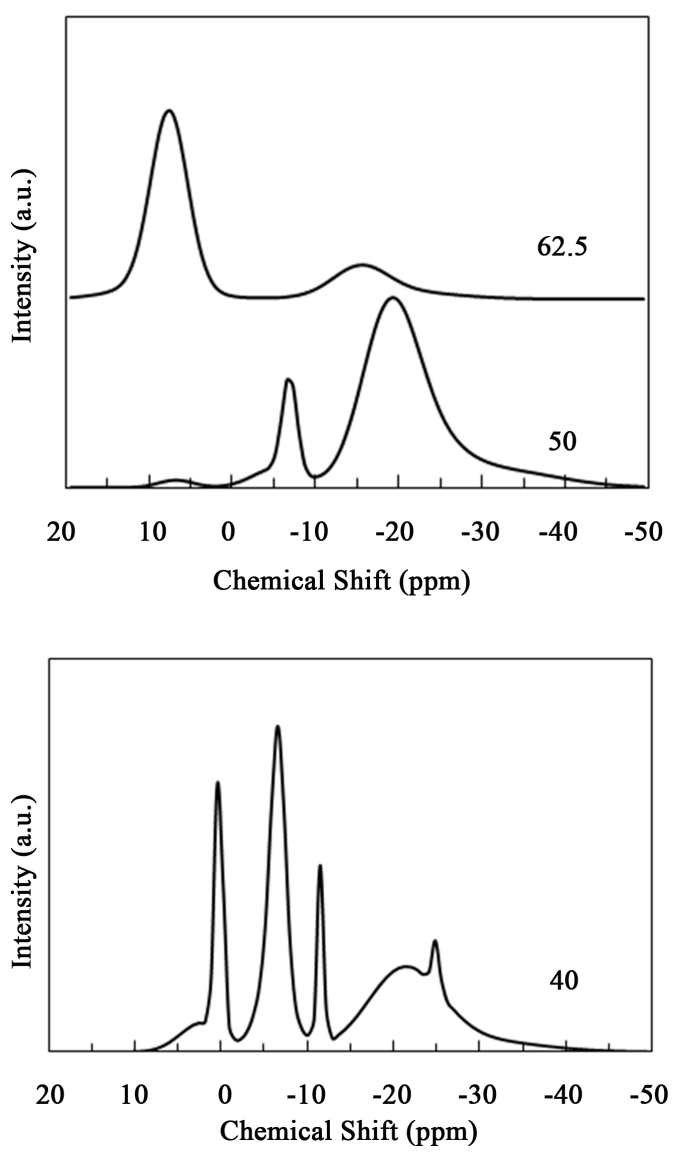

Figure 4. ${ }^{31} \mathrm{PNMR}$ spectra of binary $\mathrm{xAg}_{2} \mathrm{O} \cdot(100-\mathrm{x}) \mathrm{P}_{2} \mathrm{O}_{5}$ glasses $(\mathrm{x}=40,50$ and 62.5 mol\%).

Table 1. The approximate chemical shift ranges for different types of phosphate tetrahedra in silver phosphate glasses.

\begin{tabular}{|c|c|c|c|c|c|c|c|c|}
\hline Composition mol\% & $\begin{array}{c}\mathrm{Q}^{3} \\
\mathrm{ppm}\end{array}$ & $\begin{array}{c}\text { Area } \\
\%\end{array}$ & $\begin{array}{c}\mathrm{Q}^{2} \\
\mathrm{ppm}\end{array}$ & $\begin{array}{c}\text { Area } \\
\%\end{array}$ & $\begin{array}{c}\mathrm{Q}^{1} \\
\mathrm{ppm}\end{array}$ & $\begin{array}{c}\text { Area } \\
\%\end{array}$ & $\begin{array}{c}\mathrm{Q}^{0} \\
\mathrm{ppm}\end{array}$ & $\begin{array}{c}\text { Area } \\
\%\end{array}$ \\
\hline & & & & & -11.5 & & - & 0 \\
\hline \multirow[t]{2}{*}{$40 \mathrm{Ag}_{2} \mathrm{O}-60 \mathrm{P}_{2} \mathrm{O}_{5}$} & -24.9 & 9.6 & -21.25 & 31.5 & -6.6 & 58.8 & - & 0 \\
\hline & & & & & 0.25 & & - & 0 \\
\hline $50 \mathrm{Ag}_{2} \mathrm{O}-50 \mathrm{P}_{2} \mathrm{O}_{5}$ & - & - & -18.8 & 84.18 & -6.87 & 14.19 & 6.75 & 1.6 \\
\hline $62.5 \mathrm{Ag}_{2} \mathrm{O}-37.5 \mathrm{P}_{2} \mathrm{O}_{5}$ & - & - & -19.12 & 9.34 & -15.4 & 14.58 & 7.57 & 76.07 \\
\hline
\end{tabular}

apparent differences in peak position, intensity and relative area under the resonance spectra during transition from one composition to another. Significant changes in these parameters are observed with increasing $\mathrm{Ag}_{2} \mathrm{O} / \mathrm{P}_{2} \mathrm{O}_{5}$ molar ratio. The position of peaks are shown to move toward less shielded phosphate units, since spectra of less negative chemical shift are observed with increasing $\mathrm{Ag}_{2} \mathrm{O}$ concentrations. Both type and concentration of phosphate different species can be defined by analyzing the resonance spectra via band integration as well as deconvoltion. Figure 5 shows deconvoluted NMR spectra of glasses containing 50 and $62.5 \mathrm{~mol} \% \mathrm{Ag}_{2} \mathrm{O}$, as examples. 

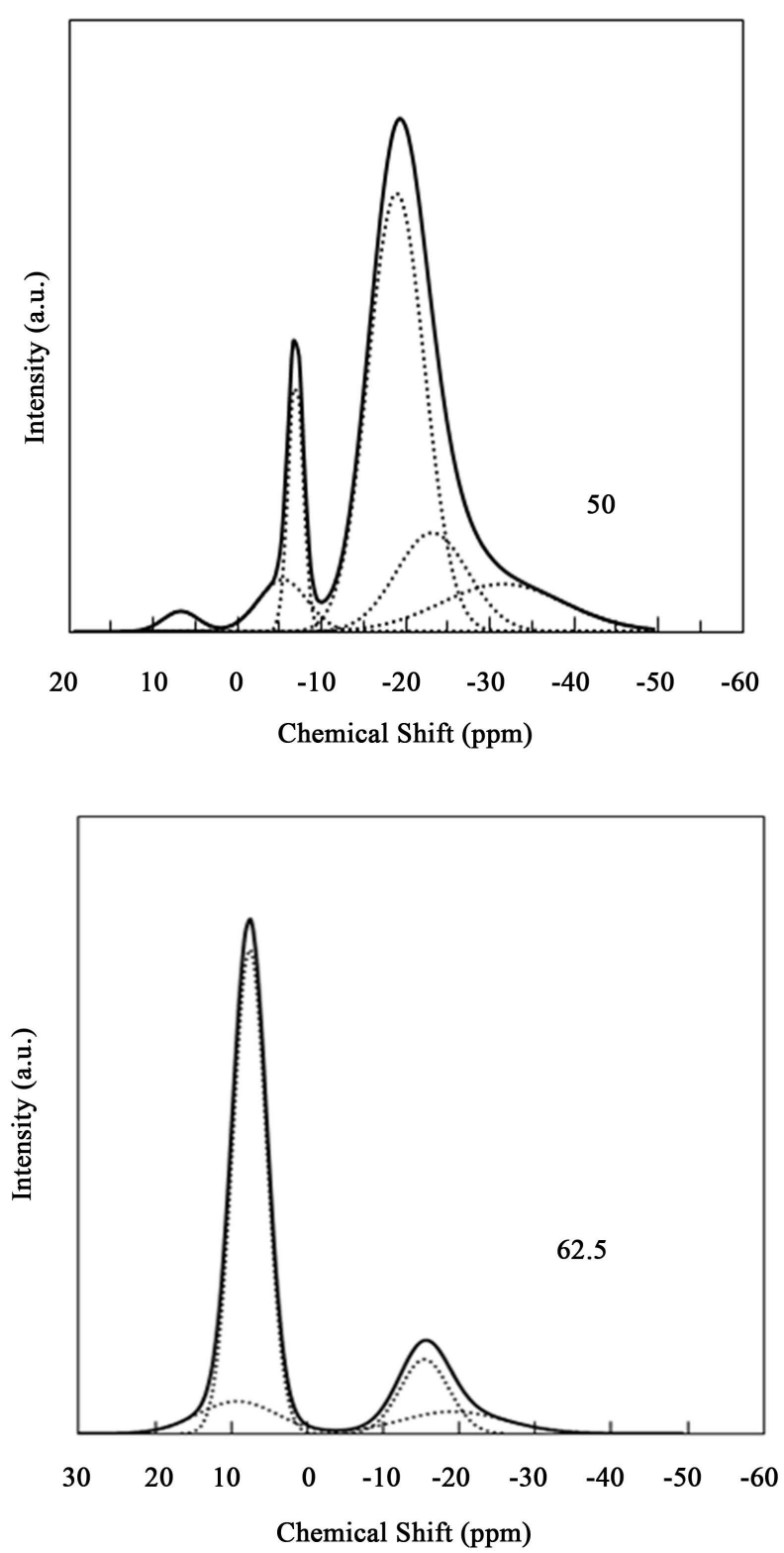

Figure 5. Deconvoluted NMR spectra of 50 and $62.5 \mathrm{~mol} \% \mathrm{Ag}_{2} \mathrm{O}$ glasses.

Based on analyzed data, Table 1, mixtures composed of few ultraphosphate and relatively high concentration from metaphosphate species are the main distributed units in matrix of glass of $40 \mathrm{~mol} \% \mathrm{Ag}_{2} \mathrm{O}$. In this case, $\mathrm{PO}_{4}$ groups with limited quantity of $\mathrm{Q}^{3}$ and dominant $\mathrm{Q}^{2}$ and $\mathrm{Q}^{1}$ types are the structure species which build up metaphosphatephase. On the other hand, phosphate units containing mixture of $\mathrm{Q}^{2}$ and $\left(\mathrm{Q}^{1}\right)$ are the representative building units for pyrophosphate composition ( $50 \mathrm{~mol} \% \mathrm{Ag}_{2} \mathrm{O}$ ). Finally NMR spectra of orthophosphate network reveal that both $\mathrm{Q}^{1}$ and $\mathrm{Q}^{0}$ are the main components of orthophosphate composition. The latter type is dominant feature of crystallization of glass containing $62.5 \mathrm{~mol} \%$ silver oxide.

Generally, three resolved isotropic resonance line spectra were appeared between $0 \mathrm{ppm}$ and $-12 \mathrm{ppm}$ for glass of $40 \mathrm{~mol} \% \mathrm{Ag}_{2} \mathrm{O}$. The resonance at $0,-7$ 
and $-12 \mathrm{ppm}$ are assigned to composite signals from the three phosphorus nuclei of the mixed meta and pyrophosphate groups (formally non-equivalent but accidentally having degenerate chemical shifts). One of the resonance lines is due to $\mathrm{Q}^{1}$ in ring site, the other in chain site and the third characterized units of double bond and or P-OH groups [19] [20] [21] [22]. On the other hand, based on NMR observations, orthophosphates and end groups of polyphosphates are not probable to be formed in this glass (40 mol\%). This is because they resonate a different frequency (more chemical shift) than chain containing meta phosphates species [22]. Based on NMR chemical shift, it can clearly suggest that a change in hydration state has also to be involved [21] [22]. For example, anhydrous silver pyrophosphate resonates around $1 \mathrm{ppm}$, while the signal from pyrophosphate containing dihydrogen or $\mathrm{P}-\mathrm{OH}$ bonds is observed at -8 to -12 ppm. It can be seen from Figure 3 and Table 1 that positive chemical shift differences of more than $8 \mathrm{ppm}$ to higher frequency are observed on going from central resonance of sample containing $40 \mathrm{~mol} \% \mathrm{Ag}_{2} \mathrm{O}$ to end resonance of glass of $62.5 \mathrm{~mol} \% \mathrm{Ag}_{2} \mathrm{O}$.

It was confirmed previously that changes in modifier to phosphorus ratio has an effective influence on both structure and properties of glasses [14] [21] [22]. For the values $\mathrm{R}=0,1,2$, and 3, only specific type of structural unit can exist as the main structure; $\mathrm{Q}^{3}, \mathrm{Q}^{2} \mathrm{Q}^{1}$ and $\mathrm{Q}^{0}$ unit, respectively. The NMR spectra shown in Figure 4 are correlated to great extent with values of $\mathrm{R}$. For the region $0<\mathrm{R}$ $<1$ (40 mol\% $\mathrm{Ag}_{2} \mathrm{O}, \mathrm{R}=0.67$ as an example), only a mixture of $\mathrm{Q}^{3}$ and $\mathrm{Q}^{2}$ units are found as metaphosphate species. For the region $\mathrm{R}=1\left(50 \mathrm{~mol} \% \mathrm{Ag}_{2} \mathrm{O}\right)$, only $\mathrm{Q}^{2}$ and $\mathrm{Q}^{1}$ and limited concentration from $\mathrm{Q}^{0}$ units are found. In this situation, the concentration of $\mathrm{Q}^{2}$ is still higher than that of $\mathrm{Q}^{1}+\mathrm{Q}^{0}$. For the region of $\mathrm{R}>1$ (62.5 mol\% $\mathrm{Ag}_{2} \mathrm{O}, \mathrm{R}=1.6$ ), $\mathrm{Q}^{0}$ and $\mathrm{Q}^{1}$ types are found and there is no any traces from $\mathrm{Q}^{2}$ can be detected. Specifically, $\mathrm{Q}^{0}$ is the dominant with relative concentration of (0.79) which means that $79 \%$ from the total $\mathrm{Q}^{\mathrm{n}}$ is found in $\mathrm{Q}^{0}$. This high percentage of $\mathrm{Q}^{0}$ lent support that major phosphate units are found in orthophosphate type [23]. As a consequence, respectively, metaphosphates with no $\left(\mathrm{Q}^{0}\right)$, pyrophosphate with limited $\mathrm{Q}^{0}$ and orthophosphate with dominant concentration of $\left(\mathrm{Q}^{0}\right)$ are the main species in the investigated glasses of 40,50 and $62.5 \mathrm{~mol} \% \mathrm{Ag}_{2} \mathrm{O}$. Because of the high concentration of $\mathrm{NBO}$ in glass of 62.5 mol\% $\mathrm{Ag}_{2} \mathrm{O}$, silver orthophosphate $\mathrm{Ag}_{3} \mathrm{PO}_{4}$ species are the main crystal phase which is additionally identified by XRD and EDP pattern of this glass.

As discussed, $\mathrm{Ag}_{3} \mathrm{PO}_{4}$ structural species are shared with significant higher relative concentration (79\%) in glass formation. At this composition, the phosphatetetrahedral units containing four NBO's and no BO's are formed in glass of $62.5 \mathrm{~mol} \% \mathrm{Ag}_{2} \mathrm{O}$. Any further addition of modifier to this composition would result in limiting depolymerization of the phosphate network. Therefore the 62.5 $\mathrm{mol} \% \mathrm{Ag}_{2} \mathrm{O}$ is the maximum limit of glass modification, beside it contains some of specific crystallized species from sliver orthophosphate $\mathrm{Ag}_{3} \mathrm{PO}_{4}$. These peculiarities may lead one to recommend some of the studied glasses to be used in the field of biomedical applications [24] [25]. This may because, it contains 
$\mathrm{Ag}_{3} \mathrm{PO}_{4}$ apatite phase which play the role of bioactivity. Surprising, this apatite phase is constructed in its crystalline counterpart which would in turns promotes their interaction with living cells. In addition, silver in apatite phase is important as antibacterial and antifungal agent, particularly when is used in dental applications.

\section{FTIR Spectroscopy}

The movement from a high cross-linked $\mathrm{Q}^{3}$ structure, to chain-like $\mathrm{Q}^{2}$ network, to depolymerized $\mathrm{Q}^{1} / \mathrm{Q}^{0}$ glasses with increasing $\mathrm{Ag}_{2} \mathrm{O}$ concentration can be monitored by a variety of other spectroscopic probes [22]-[27]. In pure vitreous $\mathrm{P}_{2} \mathrm{O}_{5}$ and in glass of high contents of $\mathrm{P}_{2} \mathrm{O}_{5}$, the basic structure entities are $\mathrm{PO}_{4}$ tetrahedra forming predominantly three-dimensional network (3D) with $\mathrm{Q}^{3}$ type of structural units [7] [9]. Addition of modifier, part of 3D-network would depolymerize and $2 \mathrm{D}$ chain structure is simultaneously formed $\left(\mathrm{Q}^{2}\right.$ structural units). NMR Data of present glasses indicated that, the fraction of 3D network structure decreases quickly and chain structure created by $\mathrm{Q}^{2}$ units dominates to the network of the glass containing $50 \mathrm{~mol} \% \mathrm{Ag}_{2} \mathrm{O}$. More addition of $\mathrm{Ag}_{2} \mathrm{O}$ at expense of $\mathrm{P}_{2} \mathrm{O}_{5}$ the two dimensional chain structure decreases and ring like structure containing mainly $\mathrm{Q}^{1}$ and $\mathrm{Q}^{0}$ units are formed. Based on this information, the following observations can be extracted from FTIR spectra upon increasing $\mathrm{Ag}_{2} \mathrm{O}$ content. From Figure 6 it can observe that:

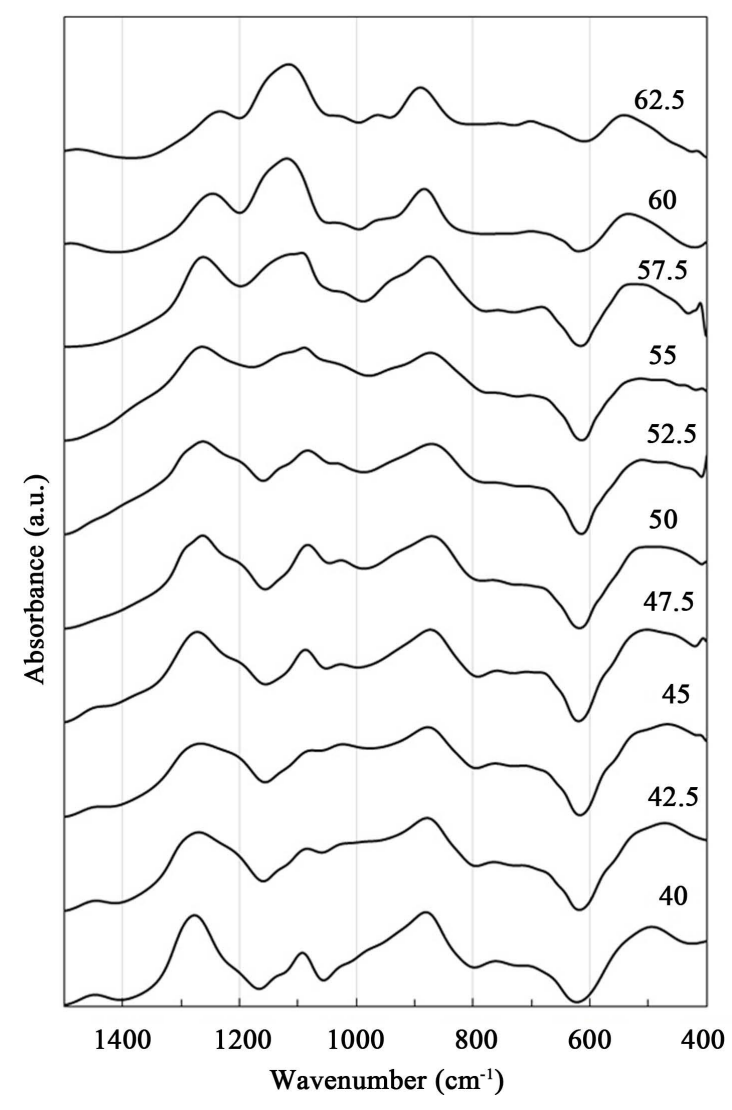

Figure 6. FTIR spectra of $\mathrm{xAg}_{2} \mathrm{O}(100-\mathrm{x}) \mathrm{P}_{2} \mathrm{O}_{5}$ glasses. 
1. The intensity and area of the band centered at about $1290 \mathrm{~cm}^{-1}$, attributed to the absorption of $\mathrm{P}=\mathrm{O}$ and $\left(\mathrm{PO}_{2}\right)$ in $\mathrm{Q}^{2}$ chains [10] are both decreased quickly with increasing $\mathrm{Ag}_{2} \mathrm{O}$ content. This leads that the long chain is reduced, and thus the structure of phosphate glasses is composed from shorter chain of $\mathrm{Q}^{1}$ and/or isolated tetrahedral $\left(\mathrm{Q}^{0}\right)$ structural unit [9] [27] [29].

2. The wide humplies in the region between $800-1200 \mathrm{~cm}^{-1}$ becomes narrower and shifted to higher wavenumber. The intensity and band area are both changed with increasing $\mathrm{Ag}_{2} \mathrm{O}$ concentration. For the last composition, its centering at $\left(1140 \mathrm{~cm}^{-1}\right)$ indicates increasing number of $\mathrm{Q}^{0}$ and $\mathrm{Q}^{1}$ units [28] [30].

3. The area and intensity of the broad band in the region $620-830 \mathrm{~cm}^{-1}$ showed decreasing trends and its center $\left(\mathrm{ca} 680 \mathrm{~cm}^{-1}\right)$ becomes narrower. It is referred to the stretching vibration of oxygen atoms in P-O-P bridges [29] [30]. Decreasing area of this band leads to decreasing concentration of bridging oxygen linked between two phosphorus ions. This leads to increasing NBO in phosphate network.

Both NMR and FTIR data imply mainly considerable fragments or depolymerization of the phosphate network with an increase of $\mathrm{Ag}_{2} \mathrm{O}$ content. This is in harmony with the work presented by Hoppe [31], since it was concluded that the network depolymerization is the dominant principle in modified phosphate glasses.

We consider that $\mathrm{Ag}_{2} \mathrm{O}$ as a glass modifier enters the glass by breaking up the $\mathrm{P}-\mathrm{O}-\mathrm{P}$ bonds and may introduce coordination defects along with $\mathrm{NBO}$ atoms in the studied glasses. This leads that the long chain is lowered, and thus the structure of $\mathrm{P}_{2} \mathrm{O}_{5}$ glasses would involve shorter chain of $\mathrm{Q}^{1}$ and/or isolated tetrahedral $\left(\mathrm{Q}^{0}\right)$ structural unit [26] [30] [31].

The areas of absorbance spectra of the "nonbridging" in $\mathrm{Q}^{2}$ stretching mode (Ca $1300 \mathrm{~cm}^{-1}$ ) decreases upon increasing $\mathrm{Ag}_{2} \mathrm{O}$ contents reaching its minimum value at $62.5 \mathrm{~mol} \% \mathrm{Ag}_{2} \mathrm{O}$. This decreasing behavior may lead to progressive depolymerization of the phosphate network, as well as the increase in the average bond length of P-non-bridging oxygens presented by the band between 950 and $1200 \mathrm{~cm}^{-1}$. Figure 7 presents a correlation between different $\mathrm{Q}^{\mathrm{n}}$ upon $\mathrm{Ag}_{2} \mathrm{O}$ addition. This behavior showed some few increment in $\mathrm{Q}^{2}$ species with increasing $\mathrm{Ag}_{2} \mathrm{O}$ concentration then it abruptly decreases. A reverse behavior is seen in which it can be realized that the total NBO concentration in $Q^{1}$ and $Q^{0}$ increases at the expense of $\mathrm{Q}^{2}$ structural species. The above observation is greatly correlated with that derived from both NMR and XRD results which are discussed above, since a decrease in the average p-bond character of the P-O-P upon increasing $\mathrm{Ag}_{2} \mathrm{O}$ concentration is additionally confirmed.

\section{Conclusion}

Different phosphate glasses in meta, pyro and orthophosphate compositions have been studied by distinguished techniques. The structure of silver phosphate is slightly deviated from the alkali phosphate. This is considered due to the 


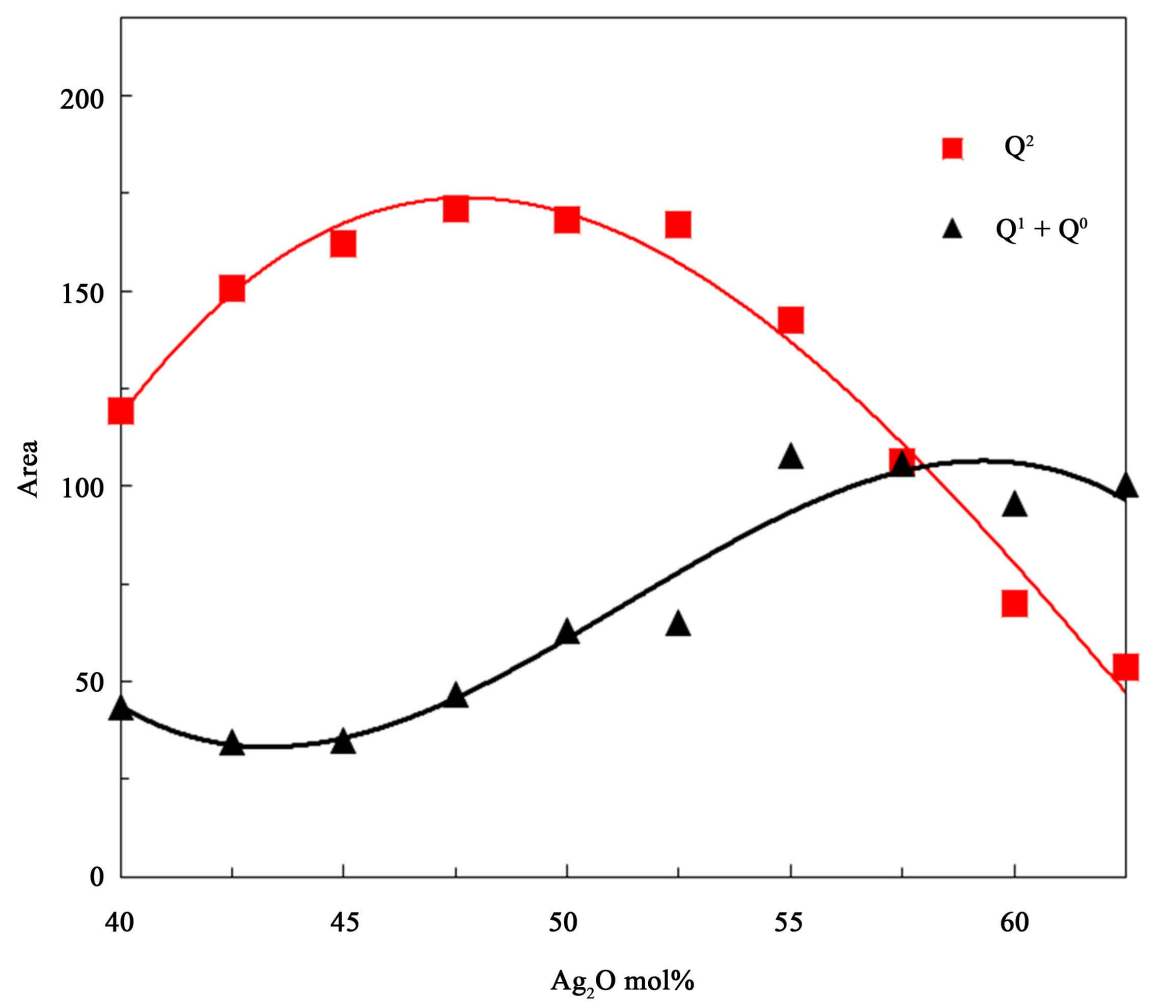

Figure 7. Representative relation between determined area of both $\mathrm{Q}^{2}$ and $\left(\mathrm{Q}^{1}+\mathrm{Q}^{0}\right)$ via $\mathrm{Ag}_{2} \mathrm{O}$ content.

difference in field strength between silver and alkali ion. X-ray and electron diffraction pattern of metaphosphate composition revealed the amorphous nature of investigated network. Pyro and orthophosphates are documented to contain some crystallized species which are correlated with increasing NBO concentration. Using the advantage of the more recent NMR spectroscopy (11.74 T), the anomalous feature found in silver metaphosphate composition has been explored for first time. Regarding this unique feature, no previous studies have been reported. ${ }^{31}$ PNMR spectra of the studied silver metaphosphate composition showed three splitting peaks of the same unit of phosphate species $\left(\mathrm{Q}^{1}\right)$ which was not evidenced in alkali metaphosphate. The diverse of spectra is diminished with increasing $\mathrm{Ag}_{2}$ Oto $\mathrm{P}_{2} \mathrm{O}_{5}$ ratio and well resolved specific peaks characterized $\mathrm{Q}^{1}$ and $\mathrm{Q}^{0}$ are obtained. FTIR analyzed data have demonstrated the inverse relation between quantity of $\mathrm{NBO}$ in $\mathrm{Q}^{2}$ and in other lower species $\left(\mathrm{Q}^{1}+\mathrm{Q}^{0}\right)$. $\mathrm{NBO}$ species reach their highest concentration in glass of $62.5 \mathrm{~mol} \% \mathrm{Ag}_{2} \mathrm{O}$. The concentration of $\mathrm{NBO}$ in this situation is high enough to construct $\mathrm{Ag}_{3} \mathrm{PO}_{4}$ apatite units which promote the biomedical application of the glass under investigation.

\section{References}

[1] Ehrt, D. (2015) Review: Phosphate and Fluoride Phosphate Optical GlassesProperties, Structure and Applications. Physics and Chemistry of Glasses-European Journal of Glass Science and Technology Part B, 56, 217-234.

[2] Hudgens, J.J. and Martin, S.W. (1993) Glass Transition and Infrared Spectra of 
Low-Alkali, Anhydrous Lithium Phosphate Glasses. Journal of the American Ceramic Society, 76, 1691-1696. https://doi.org/10.1111/j.1151-2916.1993.tb06636.x

[3] Ramzi, Z., Touhtouh, S., Nachit, W., Benkhouja, K., Taibi, M. and Hajjaji, A. (2016) Investigation of Structural and Physical Properties of xSrO- $(100-\mathrm{x}) \mathrm{P}_{2} \mathrm{O}_{5}$ Glasses. Molecular Crystals and Liquid Crystals, 627, 97-105. https://doi.org/10.1080/15421406.2015.1137137

[4] Moustafa, Y.M. and El-Egili, K. (1998) Infrared Spectra of Sodium Phosphate Glasses. Journal of Non-Crystalline Solids, 240, 144-153. https://doi.org/10.1016/S0022-3093(98)00711-X

[5] Konidakis, I., Varsamis, C.P.E., Kamitsos, E.I., Möncke, D. and Ehrt, D. (2010) Structure and Properties of Mixed Strontium-Manganese Metaphosphate Glasses. The Journal of Physical Chemistry C, 114, 9125-9138. https://doi.org/10.1021/jp101750t

[6] Brow, R.K., Tallant, D.R., Hugdens, J.J., Martin, S.W. and Irwin, A.D. (1994) The Short-Range Structure of Sodium Ultraphosphate Glasses. Journal of Non-Crystalline Solids, 177, 221-228. https://doi.org/10.1016/0022-3093(94)90534-7

[7] Mustarelli, P. (1999) The NMR Information on Phosphate Glasses: A Review. Phosphorus Research Bulletin, 10, 25. https://doi.org/10.3363/prb1992.10.0_25

[8] Hsu, S.M., Yung, S.W., Brow, R.K., Hsu, W.L., Lu, C.C., Wu, F.B. and Ching, S.H. (2010) Effect of Silver Concentration on the Silver-Activated Phosphate Glass. Materials Chemistry and Physics, 123, 172-176.

https://doi.org/10.1016/j.matchemphys.2010.03.078

[9] Liu, H.S. and Chin, T.S. (1997) Low melting PbO-ZnO-P2O5 glasses. Part 2. A structural study by Raman spectroscopy and MAS-NMR. Physics and Chemistry of Glasses, 38, 123.

[10] Gresch, R. and Müller-Warmuth, W. (1979) X-Ray Photoelectron Spectroscopy of Sodium Phosphate Glasses. Journal of Non-Crystalline Solids, 34, 127-136. https://doi.org/10.1016/0022-3093(79)90012-7

[11] Stoch, P., Szczerba, W., Bodnar, W., Ciecinska, M., Stoch, A. and Burkel, E. (2014) Structural Properties of Iron-Phosphate Glasses: Spectroscopic Studies and Ab Initio Simulations. Physical Chemistry Chemical Physics, 16, 19917-19927. https://doi.org/10.1039/C4CP03113J

[12] Egili, K.E., Doweidar, H., Moustafa, Y.M. and Abbas, I. (2003) Structure and Some Physical Properties of PbO- $\mathrm{P}_{2} \mathrm{O}_{5}$ Glasses. Physica B: Condensed Matter, 339, $237-$ 245. https://doi.org/10.1016/j.physb.2003.07.005

[13] Brow, R.K. (2000) Review: The Structure of Simple Phosphate Glasses. Journal of Non-Crystalline Solids, 263-264, 1-28. https://doi.org/10.1016/S0022-3093(99)00620-1

[14] Shelby, J. (2000) Properties of Alkali-Alkaline Earth Metaphosphate Glasses. Journal of Non-Crystalline Solids, 263-264, 271-276. https://doi.org/10.1016/S0022-3093(99)00639-0

[15] Machida, N., Ueda, A., Tanaka, H., Shigematsu, T., Nakanishi, N., Takahashi, M. and Minami, T. (1995) The Structure of AgI $\mathrm{Ag}_{2} \mathrm{MoO}_{4} \mathrm{Ag}_{2} \mathrm{PO}_{3.5}$ Glasses Studied by ${ }^{31} \mathrm{P}$ Magic Angle Spinning (MAS) NMR and Their Silver Ion Conducting Properties. Journal of Non-Crystalline Solids, 192-193, 326-329. https://doi.org/10.1016/0022-3093(95)00370-3

[16] Tsuchida, J., Schneider, J., Orlandi, A.O., Rinke, M.T. and Eckert, H. (2010) Sodium Distribution in Mixed Alkali K-Na Metaphosphate Glasses. Physical Chemistry Chemical Physics, 12, 2879-2887. 
[17] Shih, P.Y., Ding, J.Y. and Lee, S.Y. (2003) ${ }^{31}$ P MAS-NMR and FTIR Analyses on the structure of CuO-Containing Sodium Poly- and Meta-Phosphate Glasses. Materials Chemistry and Physics, 80,391-396. https://doi.org/10.1016/S0254-0584(03)00098-1

[18] Mansour, E. and El-Damrawi, G. (2010) Electrical Properties and FTIR Spectra of ZnO-PbO- $\mathrm{P}_{2} \mathrm{O}_{5}$ Glasses. Physica B: Condensed Matter, 405, 2137-2142. https://doi.org/10.1016/j.physb.2010.01.121

[19] El-Damrawi, G., Hassan, A.K. and Meikhail, M.S. (1996) Characterisation Studies of Quaternary Superionic $\mathrm{AgX}-\mathrm{Ag}_{2} \mathrm{O}-\mathrm{MoO}_{3}-\mathrm{P}_{2} \mathrm{O}_{5}$ Glasses $(\mathrm{X}=\mathrm{Cl}, \mathrm{Br})$. Physics and Chemistry of Glasses, 37, 101-105.

[20] Doweidar, H., El-Egili, K., Moustafa, Y.M. and Abbas, I. (2006) Density and DC Conductivity of $\mathrm{Fe}_{2} \mathrm{O}_{3}-\mathrm{PbO}-\mathrm{P}_{2} \mathrm{O}_{5}$ Glasses. Physics and Chemistry of Glasses Part $B$, 47, 610-618.

[21] Nowinski, J.L., Mroczkowska, M., Garbarczyk, J.E. and Wasiucionek, M. (2006) Materials Science-Poland, 24, 29.

[22] Brow, R.K., Kirkpatrick, R.J. and Turner, G.L. (1990) The Short Range Structure of Sodium Phosphate Glasses I. MAS NMR Studies. Journal of Non-Crystalline Solids, 116, 39. https://doi.org/10.1016/0022-3093(90)91043-Q

[23] Hartmann, P., Vogel, J. and Schnabel, B. (1994) NMR Study of Phosphate Glasses and Glass Ceramic Structures. Journal of Non-Crystalline Solids, 176, 157. https://doi.org/10.1016/0022-3093(94)90073-6

[24] Kirkpatrick, R.J. and Brow, R.K. (1995) Nuclear Magnetic Resonance Investigation of the Structures of Phosphate and Phosphate-Containing Glasses: A Review. Solid State Nuclear Magnetic Resonance, 5, 9-21. https://doi.org/10.1016/0926-2040(95)00042-O

[25] Schlosser, M., Frols, S., Hauf, U., Sethmann, I., Schultheiss, S., Pfeifer, F. and Kleebe, H. (2013) Combined Hydrothermal Conversion and Vapor Transport Sintering of Ag-Modified Calcium Phosphate Scaffolds. Journal of the American Ceramic Society, 96, 412-419.

[26] Hara, Y.K. and Kudo, J. (2005) Bactericidal Actions of a Silver Ion Solution on Escherichia coli, Studied by Energy-Filtering Transmission Electron Microscopy and Proteomic Analysis. Applied and Environmental Microbiology, 71, 7589-7593. https://doi.org/10.1128/AEM.71.11.7589-7593.2005

[27] Brow, R.K., Tallant, D.R., Myers, S.T. and Phifer, C.C. (1995) The Short-Range Structure of Zinc Polyphosphate Glass. Journal of Non-Crystalline Solids, 191, 45. https://doi.org/10.1016/0022-3093(95)00289-8

[28] Shih, P.Y., Yung, S.W. and Chin, T.S. (1999) FTIR and XPS Studies of $\mathrm{P}_{2} \mathrm{O}_{5}-\mathrm{Na}_{2} \mathrm{O}-$ CuO Glasses. Journal of Non-Crystalline Solids, 244, 211-222. https://doi.org/10.1016/S0022-3093(99)00011-3

[29] Chahine, A., Et-Tabirou, M. and Pascal, J.L. (2004) FTIR and Raman Spectra of the $\mathrm{Na}_{2} \mathrm{O}-\mathrm{CuO}-\mathrm{Bi}_{2} \mathrm{O}_{3}-\mathrm{P}_{2} \mathrm{O}_{5}$ Glasses. Materials Letters, 58, 2776-2780. https://doi.org/10.1016/j.matlet.2004.04.010

[30] Lai, Y.M., Liang, X.F., Yang, S.Y., Wang, J.X., Cao, L.H. and Dai, B. (2011) Raman and FTIR Spectra of Iron Phosphate Glasses Containing Cerium. Journal of Molecular Structure, 992, 84-88. https://doi.org/10.1016/j.molstruc.2011.02.049

[31] Hoppe, U. (1996) A Structural Model for Phosphate Glasses. Journal of Non-Crystalline Solids, 195, 138. https://doi.org/10.1016/0022-3093(95)00524-2 
Submit or recommend next manuscript to SCIRP and we will provide best service for you:

Accepting pre-submission inquiries through Email, Facebook, LinkedIn, Twitter, etc. A wide selection of journals (inclusive of 9 subjects, more than 200 journals)

Providing 24-hour high-quality service

User-friendly online submission system

Fair and swift peer-review system

Efficient typesetting and proofreading procedure

Display of the result of downloads and visits, as well as the number of cited articles Maximum dissemination of your research work

Submit your manuscript at: http://papersubmission.scirp.org/

Or contact njgc@scirp.org 